\title{
Implikasi standar program siaran pada tayangan edukasi dan artistik TVRI Jawa Barat
}

\author{
Lia Kurniawati ${ }^{1}$
}

${ }^{1}$ Politeknik Kridatama, Bandung, Indonesia

\begin{abstract}
ABSTRAK
Penelitian Komisi Penyiaran Indonesia membuat Pedoman Perilaku Penyiaran dan Standar Program Siaran (P3SPS). Tujuan penelitian adalah untuk melihat implikasi dan dampak yang ditimbulkan oleh tayangan televisi dua program acra Sapa Mania Legend dan Dunia Anak yang tayang di TVRI Jawa Barat yang terkait dengan kesesuaian P3SPS. Penelitian menggunakan metode deskriptif dengan observasi, wawancara, dan studi dokumentasi di lapangan. Program acara Sapa Mania Legend merupakan program musik dimana 6 lagu tahun 90-an diputarkan live dan disajikan host. List judul lagu yang akan diputarkan satu minggu sebelumnya dimunculkan di-Facebook, dan saat live, pemirsa memilih lagu yang ingin diputarkan melalui telepon interaktif. Implikasi P3SPS program Sapa Mania Legend secara dampak sosial menggunakan model komunikasi stimulus respons membawa pengaruh signifikan terhadap masyarakat melalui distribusi sosial dari pengetahuan yang didapat. Pada program Dunia Anak salah satu program artistik yang diproduksi dan ditayangkan secara live-recording atau rekaman mempunyai efek menguntungkan. Tayangan ini sebagai persyaratan basis untuk interaksi sosial dan sosialisasi awal anak-anak dalam jangka panjang; mempelajari dunia, sikap dan perilaku lebih luas; mempelajari perilaku prososial; efek pendidikan; membantu membentuk identitas; membangun imajinasi. Implikasi kedua program acara ini dapat mengajarkan norma dan nilai melalui imbalan dan hukuman simbolik untuk berbagai jenis perilaku yang disajikan. Rekomendasi untuk kedua program ini pada proses pembuatan program harus lebih jeli dalam penerapannya agar layak konsumsi masyarakat ketika ditayangkan yang dapat mempengaruhi pola pikir khalayak ramai. Selain itu TVRI Jawa Barat diharapkan mampu mensosialisasikan literasi media dan juga berperan sebagai pedoman penyiaran bagi lembaga-lembaga penyiaran lainnya serta masyarakat.
\end{abstract}

Kata-kata Kunci: Implikasi P3SPS; Sapa Mania Legend; Dunia Anak; TVRI Jawa Barat; model komunikasi stimulus respon

\section{The implication of broadcast program standard on educational and artistic program on TVRI West Java}

\begin{abstract}
The Indonesian Broadcasting Commission made Broadcasting Behavior Guidelines and Broadcast Program Standards (P3SPS). The purpose of writing this research is to find out the two programs of Sapa Mania Legend and the Dunia Anak which aired on TVRI West Java through the implications and effects caused by television shows that are not in accordance with P3SPS. The study used descriptive methods with observation, interviews, and documentation studies in the field. The Sapa Mania Legend program is a music program where 6 songs from the 90's are played live by the host. The list of song titles that will be played one week before is displayed on Facebook, and during live, viewers choose the songs that they want to play via an interactive phone. The P3SPS implication of the Sapa Mania Legend program in social impact using the stimulus respons communication model has a significant influence on the community through social distribution of the knowledge gained. In the Dunia Anak program, one artistic program that is produced and aired in live-recording or recorded has a beneficial effect. This program is a basic requirement for social interaction and early socialization for children in the long term; study the world, attitudes and behavior more broadly; study prosocial behavior; the effect of education; help in shaping the identity; build imagination. The implications of these two programs can teach norms and values through symbolic rewards and punishments for the various types of behavior presented. Recommendations for these two programs in the process of making the program must be more observant in its application so that it is suitable for public consumption when it is aired which can influence the mindset of the general public. Besides that, TVRI West Java is expected to be able to play a role on Media Literacy for the dissemination of regulations and broadcasting guidelines for other broadcasting institutions and the public
\end{abstract}

Keywords: P3SPS implications; Sapa Mania Legend; Dunia Anak; TVRI Jawa Barat; stimulus responce communication model

Korespondensi: Lia Kurniawati, S. Ikom. M.MPd. Prodi Penyiaran dan Broadcasting Politeknik Kridatama Bandung.Email: liakurniawati@politeknik-kridatama.ac.id 


\section{PENDAHULUAN}

Media massa merupakan salah satu alat komunikasi yang memiliki kemampuan dan pengaruh yang besar dalam menyampaikan pesan yang dapat tersebar luas secara cepat. Oleh sebab itu media massa dengan seiring waktu telah menjadi hal yang sangat penting bahkan telah menjadi kebutuhan bagi sebagian besar masyarakat. Media massa terdiri dari dua jenis yaitu media massa cetak dan media massa elektronik. Perkembangan dalam bidang ilmu teknologi dan informasi membuat salah satu bentuk dari media massa yaitu media massa elektronik menjadi lebih diminati dibandingkan dengan media massa cetak.

Media televisi merupakan salah satu media massa elektronik yang selalu berkembang dari waktu ke waktu dan menjadi pilihan utama sebagian besar pengguna media massa untuk mendapatkan informasi dan hiburan yang mereka butuhkan. Penyiaran televisi adalah media komunikasi massa dengar pandang yang menyalurkan siaran berupa program yang teratur dan berkesinambungan yang dapat diterima secara serentak dan bersamaan oleh masyarakat dengan perangkat penerima siaran, dikutip dari UU RI Tentang Penyiaran No. 32 tahun 2002. Perkembangan media televisi yang semakin pesat dan kompetitif menyebabkan persaingan berbagai media televisi dalam menyajikan program-program yang semakin bervariasi dalam format dan konten program televisi demi menarik perhatian masyarakat semakin sengit.

Semua media televisi berusaha menarik perhatian khalayak dengan menyajikan tayangan baik yang bertitik berat pada kualitas tontonan yang memberi dampak positif hingga tayangan yang berbeda dan hanya menarik perhatian tanpa mengindahkan beberapa aspek nilai tertentu. Setiap tayangan memiliki sasaran penonton masing-masing. Kurangnya pengetahuan khalayak umum mengenai segmentasi tayangan televisi juga dapat menyebabkan suatu kelompok atau segmentasi tertentu menikmati tontonan yang tidak sesuai dengan segmentasi tersebut, kesalahan konsumsi tayangan televisi dapat menimbulkan efek-efek yang tidak diinginkan bahkan meskipun dalam skala kecil sekalipun.

Kurniadi memaparkan, "Budaya jurnalistik adalah suatu proses yang memusatkan perhatian pada masa lalu dan representasi kesinambungan sejarah maupun inovasi dalam nilai, praktik dan kebijakan jurnalistik yang dimunculkan melalui sisi ideologis dan pola pemberitaan sejak proses pencarian, pengumpulan, pengolahan sampai penyajian" (Kurniadi, 2013). Sebagai tindakan nyata pemerintah untuk mengawasi penyiaran di Indonesia dan demi menghasilkan kualitas program siaran yang sesuai dengan peraturan perundang-undangan yang berlaku, diberlakukanlah Pedoman Perilaku Penyiaran dan Standar Program Siaran yang ditetapkan Komisi Penyiaran Indonesia setelah terlebih dahulu mendapat usulan dari masyarakat dan seluruh pihak asosiasi penyiaran. Kriteria tayangan televisi yang berkualitas dan berdampak positif bagi masyarakat.

Komisi Penyiaran Indonesia (KPI) dalam Pedoman Perilaku Penyiaran dan Standar Program Siaran, mempertimbangkan fakta bahwa dalam rangka pengaturan perilaku lembaga penyiaran di Indonesia dibutuhkan suatu pedoman yang wajib dipatuhi agar pemanfaatan frekuensi radio sebagai ranah publik yang merupakan sumber daya alam terbatas dapat senantiasa ditujukan untuk kemaslahatan masyarakat sebesar-besarnya. Dan bahwa dengan keberadaan lembagalembaga penyiaran di Indonesia harus disusun pedoman yang mampu mendorong lembaga penyiaran untuk memperkukuh integrasi sosial, terbinanya watak dan jati diri bangsa yang beriman dan bertakwa, mencerdaskan kehidupan bangsa, memajukan kesejahteraan umum, dalam rangka membangun masyarakat yang mandiri, demokratis, adil, dan sejahtera.

Dalam Peraturan Komisi Penyiaran Indonesia Nomor 03 Tahun 2007 tentang Standar Program Penyiaran, Pedoman Perilaku Penyiaran adalah ketentuan-ketentuan bagi lembaga penyiaran yang ditetapkan oleh Komisi Penyiaran Indonesia sebagai panduan tentang batasan perilaku penyelenggaraan penyiaran dan pengawasan penyiaran nasional. Sementara itu, Standar Program Siaran adalah standar isi siaran yang berisi tentang batasan- 
batasan, pelarangan, kewajiban, dan pengaturan penyiaran, serta sanksi berdasarkan Pedoman Perilaku Penyiaran yang ditetapkan oleh KPI.

Dalam Peraturan Komisi Penyiaran Indonesia tersebut diatas ditambahkan pula, Program Siaran yang dimaksudkan adalah program yang berisi pesan atau rangkaian pesan dalam bentuk suara, gambar, suara dan gambar, atau yang berbentuk grafis, atau karakter, baik yang bersifat interaktif maupun tidak, yang disiarkan oleh lembaga penyiaran. Dalam Peraturan Pemerintah Republik Indonesia Nomor 50 Tahun 2005 menyebutkan bahwa Lembaga Penyiaran adalah penyelenggara penyiaran baik lembaga penyiaran publik, lembaga penyiaran swasta, lembaga penyiaran komunitas, maupun lembaga penyiaran berlangganan yang dalam melaksanakan tugas, fungsi, dan tanggung jawabnya berpedoman pada peraturan perundang-undangan yang berlaku.

Penelitian tentang Implementasi Pedoman Perilaku Penyiaran dan Standar Program Siaran ini dilakukan untuk mengamati penerapan Pedoman Perilaku Penyiaran dan Standar Program Siaran secara nyata di TVRI Jawa Barat. Menurut PPRI Nomor 11 Tahun 2005, dimana TVRI Jawa Barat merupakan lembaga penyiaran publik yaitu lembaga penyiaran yang berbentuk badan hukum yang didirikan oleh Negara, bersifat independen, netral, tidak komersial, dan berfungsi memberikan layanan untuk kepentingan masyarakat.

\section{METODE PENELITIAN}

Penelitian mengenai Penerapan Pedoman Perilaku Penyiaran dan Standar Program Siaran pada program "Sapa Mania Legend", dan "Dunia Anak" yang ditayangkan di TVRI Jawa Barat memiliki maksud dan tujuan yaitu memberi penjelasan mengenai bagaimana peran media televisi untuk memberi tayangan yang baik untuk khalayak, berdasarkan hal tersebut maka penelitian ini merupakan penelitian yang bersifat deskriptif (description research), yaitu menyajikan hasil penelitian melalui penjelasan secara mendalam.

Metode atau teknik pengumpulan data

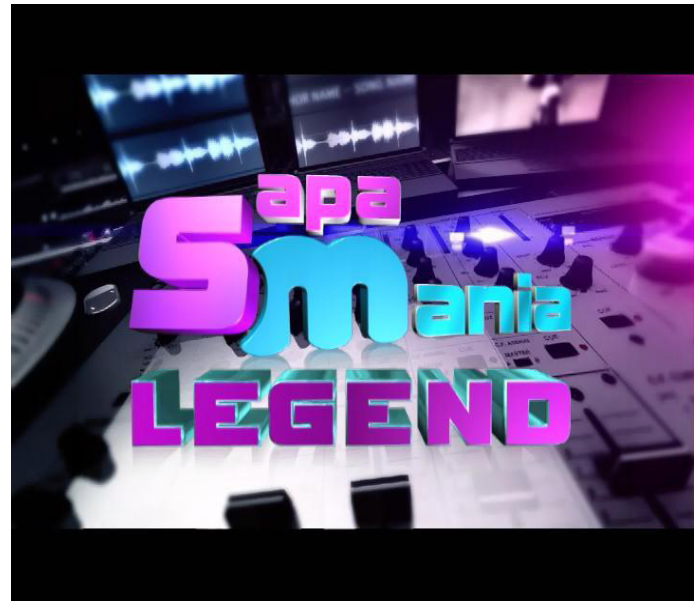

Sumber: Web program acara TVRI Jabar, 2017

\section{Gambar 1 Sapa Mania Legend}

dalam penelitian ini dilakukan secara kualitatif dengan menggunakan metode observasi yaitu mengamati secara langsung ke tempat penelitian, metode wawancara yaitu mengumpulkan data dengan mengajukan beberapa pertanyaan yang perlu diketahui kepada nara sumber yang memiliki kemampuan dan wewenang untuk memberikan data yang sebenar-benarnya demi menyelesaikan penelitian, dan metode studi pustaka yaitu mengumpulkan data dari berbagai macam sumber seperti buku, jurnal, dan sumber data primer lainnya.

Sapa Mania Legend merupakan salah satu program artistik yang diproduksi dan ditayangkan oleh TVRI Jawa Barat, tayang secara live setiap hari Sabtu, Minggu, dan Senin dengan durasi 60 menit dimulai dari pukul 18.00 WIB hingga pukul 19.00 WIB. Sapa Mania Legend merupakan program musik dimana 6 lagu zaman dulu (tahun 90-an ke bawah) diputarkan live dan disajikan oleh host, list judul lagu yang akan diputarkan sudah dari satu minggu sebelumnya dimunculkan di-Facebook, dan begitu live pemirsa memilih lagu yang ingin diputarkan melalui telepon interaktif.

Penggunaan nama program Sapa Mania Legend itu sendiri memiliki makna yaitu sapa artinya menyapa, mania adalah publik atau masyarakat dan legend disini adalah artisartis terkenal dan digandrungi pada masanya. Program Sapa Mania Legend mulai menjadi "booming" dan diminati ketika para penonton banyak berinteraksi dan mengomentari akun Facebook Sapa Mania Legend, demi menghargai 
apresiasi para penonton yang mengomentari di akun Facebook Sapa Mania Legend maka dimunculkanlah komen-komen tersebut saat live program Sapa Mania Legend.

Hasilnya, antusiasme penonton semakin besar dan komentar semakin bertambah hingga akhirnya Sapa Mania Legend memutuskan untuk menghadirkan 2 penonton Sapa Mania Legend setiap episode untuk bertemu langsung dengan pembawa acara dan tampil di acara Sapa Mania Legend. Setelah mendapat respons yang semakin positif, program Sapa Mania Legend mengundang penyanyi "legend" langsung untuk bernyanyi dan disaksikan langsung oleh penonton yang dengan suka rela berpartisipasi dan datang ke Studio.

Untuk selalu menghargai apresiasi penonton, program Sapa Mania Legend mengusung konsep "hargai penonton-mu dengan shot-mu", yaitu pengambilan shot atau komposisi shot lebih didominasi shot kepada penonton dibanding kepada penyanyi atau pengisi acara dengan skala perbandingan jumlah shot penonton dan pengisi acara adalah 70:30, 70 untuk penonton dan 30 untuk pengisi acara.

Distribusi sosial dari pengetahuan yang didapatkan dari program Sapa Mania Legend ini adalah salah satu efek media yang besar dan diantisipasi secara luas. Kapasitas mereka untuk memberikan informasi atau menginformasikan masyarakat skala besar dengan cara konsisten dengan kebutuhan ekonomi modern dan proses demokrasi partisipan. Telah lama diasumsikan bahwa program media dan penyiaran telah menambah banyak aliran informasi publik dan pemrogram acara membantu mengubah perbedaan pengetahuan yang disebabkan oleh ketidaksetaraan pendidikan dan posisi sosial.

Secara umum, motivasi dan kegunaan yang dirasakan memengaruhi informasi dan pembelajaran khalayak. Dan faktor-faktor inilah yang datang lebih dari konteks sosial daripada media. Difusi diferensial dari teknologi informasi baru yang berbasis komputer juga dapat meningkatkan pembagian program acara Televisi, dan hal ini dikaitkan dengan live streaming yang TVRI Jabar selenggarakan menggunakan website resmi TVRI Jabar sehingga ketika khalayak tertinggal pada jam tayang yang sudah ditentukan dapat dengan mudah menemukan dan ditonton kembali secara live kapan saja dan dimana saja.

Secara dampak sosial dari implementasi perilaku penyiaran pada kedua program acara ini adalah bahwa media memainkan peran dalam sosialisasi awal pada anak-anak dan sosialisasi jangka panjang dari orang dewasa yang secara luas diyakini walaupun sifat dasar masalah ini sangat sulit dibuktikan. Penelitian longitudinal mengenai perkembangan yang jarang terhadap program ini menghasilkan bukti nyata dari sosialisasi program. Logisnya bahwa program ini dapat mengajarkan norma dan nilai melalui imbalan dan hukuman simbolik untuk berbagai jenis perilaku yang disajikan. Pandangan alternatifnya merupakan proses pembelajaran melalui mana sebagai khalayak belajar dan bagaimana bertindak dalam situasi tertentu dan pengharapan sejalan dengan peran dan status yang berlaku di masyarakat.

Studi awal mengenai program anak-anak danmengenai penggunaan media oleh anak-anak menunjukkan kecenderungan anak-anak untuk mendapatkan pelajaran mengenai kehidupan dan menghubungkannya dengan pengalaman mereka sendiri. Penelitian mengenai konten juga menarik perhatian terhadap penyajian sistematis akan gambaran mengenai kehidupan sosial yang dapat secara kuat membentuk

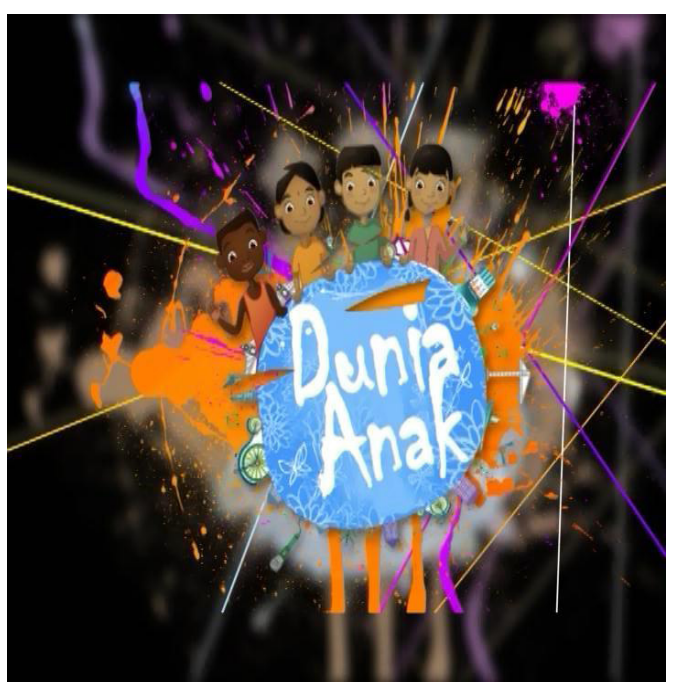

Sumber: Web program acara TVRI Jabar, 2017

Gambar 2 Program Dunia Anak 
pengharapan dan aspirasi anak-anak.

Dunia Anak merupakan salah satu program artistik yang diproduksi dan ditayangkan oleh TVRI Jawa Barat, tayang secara live-recording atau rekaman yang menayang program dengan format langsung. Tayang setiap hari sabtu dengan durasi 30 menit dari pukul 15.30 WIB hingga pukul 16.00 WIB.

Dunia Anak merupakan program edukasi yang bertujuan untuk sarana aktualisasi minat dan bakat anak, pada dasarnya semua manusia saat mengaktualisasikan dirinya akan merasakan suatu kepuasan atau kesenangan. Oleh sebab itu, Dunia Anak memberikan wadah untuk anak-anak mengaktualisasikan diri mereka.

Aktualisasi diri sebenarnya bisa melalui berbagai macam cara, salah satu cara dalam mengaktualisasikan diri yaitu melalui berpenampilan. Dalam program Dunia Anak, anak-anak mengaktualisasikan diri mereka melalui kesenian dan prestasi. Oleh sebab itu, segmen-segmen dalam program Dunia Anak diisi dengan penampilan para pengisi acara anak-anak seperti menari, dan bernyanyi serta mengetengahkan budaya lokal yaitu budaya Jawa Barat dalam sebagian besar penampilannya.

Selain diisi dengan penampilan para pengisi acara anak-anak, program Dunia Anak juga diisi dengan segmen wawancara dengan para anak yang berprestasi baik dalam bidang akademik maupun bidang non-akademik, hal ini bertujuan untuk memotivasi anak-anak lainnya yang menonton program Dunia Anak dalam berprestasi baik di bidang akademik maupun bidang non-akademik, lalu ada segmen sains ringan "Sekarang Aku Tahu", sains ringan untuk memberi pengetahuan ilmu fisika dan pembuktian teori fisika ringan yang berguna namun tetap menyenangkan bagi anak-anak.

Televisi Republik Indonesia (TVRI) Jawa Barat merupakan lembaga penyiaran publik lokal Jawa Barat. Memiliki slogan "Sobat Urang Sararea", TVRI Jawa Barat berdiri pada tanggal 11 Maret 1987, berlokasi di jalan Cibaduyut Raya No.269 Bandung, luas areal perkantoran $47.627 \mathrm{~m} 2$. Jangkauan siaran $35.862 \mathrm{Km}$ dengan kekuatan transmisi antara $100 \mathrm{~s} / \mathrm{d} 20.000$ Watt.

Visi dari TVRI Jawa Barat adalah

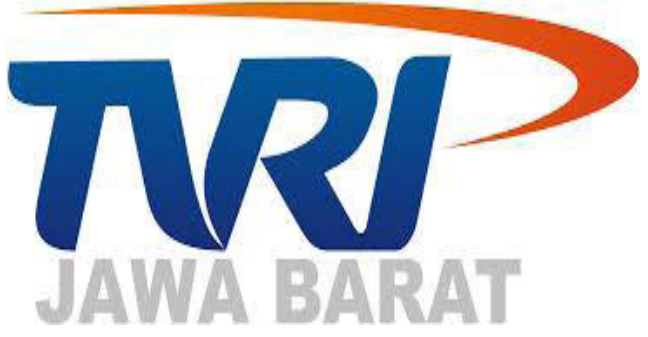

Sumber Web TVRI Jabar, 2017

\section{Gambar 3 Logo TVRI Jawa Barat}

terwujudnya TVRI Jawa Barat sebagai media utama penggerak pemersatu bangsa. Sedangkan Misi TVRI Jawa Barat adalah sebagai berikut: (a) menyelenggarakan siaran yang menghibur, mendidik, informatif, secara netral, berimbang, sehat dan beretika untuk membangun budaya bangsa dan mengembangkan persamaan dalam keberagaman, (b) menyelenggarakan layanan siaran multiplatform yang berkualitas dan berdaya saing. menyelenggarakan tata kelola lembaga yang modern, transparan dan akuntabel,c) menyelenggarakan pengembangan dan tata usaha yang sejalan dengan tugas pelayanan publik, (d) menyelenggarakan pengelolaan sumber daya proaktif dan handal guna meningkatkan pelayanan publik dan kesejahteraan pegawai, dan (e) Jangkauan siaran TVRI Jawa Barat saat ini didukung oleh beberapa satuan transmisi yang tersebar di wilayah Jawa Barat.

Metode atau teknik pengumpulan data dalam penelitian mengenai Penerapan Pedoman Perilaku Penyiaran dan Standar Program Siaran pada program "Sapa Mania Legend", dan "Dunia Anak" ini dilakukan secara kualitatif dengan menggunakan metode observasi yaitu mengamati secara langsung ke tempat penelitian, metode wawancara yaitu mengumpulkan data dengan mengajukan beberapa pertanyaan yang perlu diketahui kepada narasumber yang memiliki kemampuan dan wewenang untuk memberikan data yang sebenar-benarnya demi menyelesaikan penelitian, dan metode studi pustaka yaitu mengumpulkan data dari berbagai macam sumber seperti buku, dan jurnal. Jadwal dan waktu penelitian Penerapan Pedoman Perilaku Penyiaran dan Standar Program Siaran pada program "Sapa Mania- Legend", dan "Dunia Anak" disajikan dalam tabel 1. 
Tabel 1 Jadwal dan Waktu Penelitian

\begin{tabular}{|c|c|c|c|}
\hline No & Waktu & Keterangan & Sumber \\
\hline 1 & $06 / 03 / 2017$ & Pengenalan tempat penelitian & Bpk. Arif / Marketing Division \\
\hline 2 & $8 / 03 / 2017$ & Observasi tempat penelitian & Bpk. Arif / Marketing Division \\
\hline 3 & $13 / 03 / 2017$ & $\begin{array}{l}\text { Observasi produksi program Sapa Mania } \\
\text { Legend }\end{array}$ & $\begin{array}{l}\text { Bpk. Muchtar / Produser Sapa } \\
\text { Mania Legend }\end{array}$ \\
\hline 4 & $14 / 03 / 2017$ & $\begin{array}{l}\text { Wawancara tentang program Sapa Mania } \\
\text { Legend }\end{array}$ & $\begin{array}{l}\text { Bpk. Muchtar / Produser Sapa } \\
\text { Mania Legend }\end{array}$ \\
\hline 5 & $22 / 03 / 2017$ & Observasi produksi program Dunia Anak & $\begin{array}{l}\text { Ibu Wienny / Produser Dunia } \\
\text { Anak }\end{array}$ \\
\hline 6 & $24 / 03 / 2017$ & Wawancara tentang program Dunia Anak & $\begin{array}{l}\text { Ibu Wienny / Produser Dunia } \\
\text { Anak }\end{array}$ \\
\hline
\end{tabular}

Sumber: Hasil dan Proses Penelitian, 2017

\section{HASIL DAN PEMBAHASAN}

Definisi Penyiaran berdasarkan UU No. 32 Tahun 2002 tentang Penyiaran, Siaran adalah pesan atau rangkaian pesan dalam bentuk suara, gambar, atau suara dan gambar, atau yang berbentuk grafis, karakter, baik yang bersifat interaktif maupun tidak, yang dapat diterima melalui perangkat penerima siaran. Sedangkan Penyiaran adalah kegiatan pemancarluasan siaran melalui sarana pemancaran dan/atau sarana transmisi di darat, di laut, atau di antariksa dengan menggunakan spektrum frekuensi radio melalui udara, kabel, dan/atau media lainnya untuk dapat diterima secara serentak dan bersamaan oleh masyarakat dengan perangkat penerima siaran. UU No. 32 Tahun 2002 tentang Penyiaran juga menyatakan bahwa Penyiaran Televisi adalah media komunikasi massa dengar pandang, yang menyalurkan gagasan dan informasi dalam bentuk suara dan gambar secara umum, baik terbuka maupun tertutup, berupa program yang teratur dan berkesinambungan.

Berdasarkan pernyataan-pernyataan yang telah disajikan sebelumnya maka dapat ditarik kesimpulan bahwa Penyiaran Televisi adalah media komunikasi massa dengar pandang, yang menyalurkan siaran berupa program yang teratur dan berkesinambungan yang dapat diterima secara serentak dan bersamaan oleh masyarakat dengan perangkat penerima siaran.

Fungsi dan peran media Televisi, Media penyiaran televisi merupakan salah satu media massa elektronik yang selalu berkembang dari waktu ke waktu dan menjadi pilihan utama sebagian besar pengguna media massa elektronik untuk mendapatkan informasi dan hiburan yang mereka butuhkan. Karakteristik televisi yang membuatnya banyak menyita perhatian banyak orang dikarenakan kelebihan utama televisi yang menyatukan antara fungsi audio dan visual, disertai dengan kemampuan dalam memainkan berbagai warna (Cangara: 2006).

Saat mencari kesenangan, maka televisi dapat memberi hiburan, saat mengalami goncangan batin televisi dapat berperan sebagai sahabat (Widyastuti: 1997). Bila berkaca pada UU No. 32 Tahun 2002 BAB II Pasal 5 tentang Penyiaran, maka sejatinya penyiaran diarahkan untuk menjunjung tinggi pelaksanaan Pancasila dan Undang-Undang Dasar Negara Republik Indonesia Tahun 1945; menjaga dan meningkatkan moralitas dan nilai-nilai agama serta jati diri bangsa; meningkatkan kualitas sumber daya manusia; menjaga dan mempererat persatuan dan kesatuan bangsa; meningkatkan kesadaran ketaatan hukum dan disiplin nasional; menyalurkan pendapat umum serta mendorong peran aktif masyarakat dalam pembangunan nasional dan daerah serta melestarikan lingkungan hidup; mencegah monopoli kepemilikan dan mendukung persaingan yang sehat di bidang penyiaran; mendorong peningkatan kemampuan perekonomian rakyat, mewujudkan pemerataan, dan memperkuat daya saing bangsa dalam era globalisasi; 
memberikan informasi yang benar, seimbang, dan bertanggung jawab; dan memajukan kebudayaan nasional.

Tayangan pada televisi pada dasarnya memiliki banyak fungsi dan salah satunya adalah sebagai fungsi pendidikan, program yang informatif akan memberikan pengaruh positif pada penonton. Namun begitu, suatu tayangan juga bisa memiliki efek negatif jika konten dari program itu sendiri mengandung unsurunsur yang tidak baik. Salah satu pengaruh positif siaran televisi adalah beberapa tayangan memberikan wawasan yang banyak seperti film dokumenter, flora dan fauna, sains dan lainnya. televisi juga mampu memberikan inspirasi untuk melakukan usaha yang sebelumnya tidak pernah dilakukan (Fatimaruz: 2013). Anak-anak merupakan penonton yang harus lebih diberi perhatian khusus tentang tayangan televisi yang cocok untuk mereka karena anak-anak akan cenderung meniru tayangan yang mereka lihat.

Efek atau dampak positif maupun negatif dari suatu tayangan meliputi 3 tahap efek pada penonton, efek-efek tersebut meliputi efek kognitif, efek afektif, dan efek behaviorial. Efek kognitif terjadi bila ada perubahan pada apa yang diketahui, dipahami, atau dipersepsi khalayak. Efek ini berkaitan dengan transmisi pengetahuan, keterampilan, kepercayaan. Efek afektif terjadi bila ada perubahan pada perasaan. Efek afektif berkaitan dengan emosi, sikap, atau nilai. Efek behavioral terjadi bila ada perubahan perilaku (Rahmat: 2012).

Masyarakat yang tidak mendapatkan banyak pengetahuan mengenai tayangan televisi juga menjadi penyebab para penonton pada akhirnya menkonsumsi tayangan yang tidak sesuai, dengan demikian, sosialisasi mengenai regulasi dan pedoman penyiaran serta Media Literacy bagi konsumen media agar penonton dapat memilih acara yang berkualitas merupakan tanggung jawab pemerintah, KPI, akademisi maupun pengelola media itu sendiri (Kriyantono: 2007).

Komisi Penyiaran Indonesia, Berdasarkan Undang-Undang Republik Indonesia No. 32 Tahun 2002 tentang Penyiaran, Komisi Penyiaran Indonesia adalah lembaga negara yang bersifat independen yang ada di pusat dan di daerah yang tugas dan wewenangnya diatur dalam Undang-Undang ini sebagai wujud peran serta masyarakat di bidang penyiaran. KPI sebagai wujud peran serta masyarakat berfungsi mewadahi aspirasi serta mewakili kepentingan masyarakat akan penyiaran. Dalam menjalankan fungsinya, KPI mempunyai wewenang: menetapkan standar program siaran; menyusun peraturan dan menetapkan pedoman perilaku penyiaran; mengawasi pelaksanaan peraturan dan pedoman perilaku penyiaran serta standar program siaran; memberikan sanksi terhadap pelanggaran peraturan dan pedoman perilaku penyiaran serta standar program siaran; melakukan koordinasi dan/atau kerjasama dengan pemerintah, lembaga penyiaran, dan masyarakat.

KPI mempunyai tugas dan kewajiban: menjamin masyarakat untuk memperoleh informasi yang layak dan benar sesuai dengan hak asasi manusia; ikut membantu pengaturan infrastuktur bidang penyiaran; ikut membangun iklim persaingan yang sehat antarlembaga penyiaran dan industry terkait; memelihara tatanan informasi nasional yang adil, merata, dan seimbang; menampung, meneliti, dan menindaklanjuti aduan, sanggahan, serta kritik dan apresiasi masyarakat terhadap penyelenggaraan penyiaran; dan menyusun perencanaan pengembangan sumber daya manusia yang menjamin profesionalitas di bidang penyiaran.

Dengan keberadaan lembaga-lembaga penyiaran di Indonesia dan dalam rangka pengaturan perilaku lembaga penyiaran di Indonesia dibutuhkan suatu pedoman yang wajib dipatuhi agar pemanfaatan frekuensi radio sebagai ranah publik yang merupakan sumber daya alam terbatas dapat senantiasa ditujukan untuk kemaslahatan masyarakat sebesarbesarnya maka Komisi Penyiaran Indonesia menetapkan Pedoman Perilaku Penyiaran dan Standar Program Siaran.

Definisi dan Tujuan P3 SPS, Peraturan Komisi Penyiaran Indonesia No.01/P/ KPI/03/2012 menyatakan bahwa Pedoman Perilaku Penyiaran adalah ketentuan-ketentuan bagi lembaga penyiaran yang ditetapkan oleh Komisi Penyiaran Indonesia sebagai panduan 
tentang batasan perilaku penyelenggaraan penyiaran dan pengawasan penyiaran nasional. Sementara itu, berdasarkan Peraturan Komisi Penyiaran Indonesia No.02/P/KPI/03/2012, Standar Program Siaran adalah standar isi siaran yang berisi tentang batasan-batasan, pelarangan, kewajiban, dan pengaturan penyiaran, serta sanksi berdasarkan Pedoman Perilaku Penyiaran yang ditetapkan oleh KPI.

Program Siaran yang dimaksudkan dalam Peraturan Komisi Penyiaran Indonesia adalah program yang berisi pesan atau rangkaian pesan dalam bentuk suara, gambar, suara dan gambar, atau yang berbentuk grafis, atau karakter, baik yang bersifat interaktif maupun tidak, yang disiarkan oleh lembaga penyiaran. Dalam hal ini, yang dimaksud dengan Lembaga Penyiaran adalah penyelenggara penyiaran baik lembaga penyiaran publik, lembaga penyiaran swasta, lembaga penyiaran komunitas, maupun lembaga penyiaran berlangganan yang dalam melaksanakan tugas, fungsi, dan tanggung jawabnya berpedoman pada peraturan perundang-undangan yang berlaku.

Komisi Penyiaran Indonesia dalam memutuskan Pedoman Perilaku Penyiaran dan Standar Program Siaran mempertimbangkan fakta bahwa dalam rangka pengaturan perilaku lembaga penyiaran di indonesia, dibutuhkan suatu pedoman yang wajib dipatuhi agar pemanfaatan frekuensi radio sebagai ranah publik yang merupakan sumber daya alam terbatas dapat senantiasa ditujukan untuk kemaslahatan masyarakat sebesar-besarnya. Dan bahwa dengan keberadaan lembagalembaga penyiaran di Indonesia harus disusun pedoman yang mampu mendorong lembaga penyiaran untuk memperkukuh integrasi sosial, terbinanya watak dan jati diri bangsa yang beriman dan bertakwa, mencerdaskan kehidupan bangsa, memajukan kesejahteraan umum, dalam rangka membangun masyarakat yang mandiri, demokratis, adil, dan sejahtera.

Berdasarkan Pedoman Perilaku Penyiaran dan Standar Program Siaran Bab II, Pasal 4, Pedoman Perilaku Penyiaran dan Standar Program Siaran memberi arah dan tujuan agar lembaga penyiaran: menjunjung tinggi dan meningkatkan rasa persatuan dan kesatuan
Negara Kesatuan Republik Indonesia; meningkatkan kesadaran dan ketaatan terhadaphukum dan segenap peraturan perundang-undangan yang berlaku di Indonesia; menghormati dan menjunjung tinggi norma dan nilai agama dan budaya bangsa yang multikultural; menghormati dan menjunjung tinggi etika profesi yang diakui oleh peraturan perundang-undangan; menghormati dan menjunjung tinggi prinsip-prinsip demokrasi; menghormati dan menjunjung tinggi hak asasi manusia; menghormati dan menjunjung tinggi hak dan kepentingan publik; menghormati dan menjunjung tinggi hak anakanak dan remaja; menghormati dan menjunjung tinggi hak orang dan/atau kelompok masyarakat tertentu; dan menjunjung tinggi prinsip-prinsip jurnalistik.

Untuk dapat menghasilkan suatu produksi yang bersifat imajinatif dan ekspresif, dibutuhkan perpaduan keharmonisan antara bunyi-bunyian atau efek dan tata gerak yang diproduksi dari sebuah stasiun penyiaran televisi. Berhasil tidaknya suatu program disajikan oleh broadcasting televisi adalah hasil dari "mixing olah suara dan tubuh" terpadu yagn pada akhirnya akan membuat sebuah program televisi dapat mewakili keberadaan suatu stasiun televisi tersebutyang menjadi pembeda dari stasiun-stasiun lainnya.

Dari hasil perpaduan suara yang unik dan gaya yang menarik akan tercipta beberapa hal yang tidak dapat diabaikan, untuk menicptakan suatu program berkualitas dan sesuai dengan tuntunan perundang-undangan yang berlaku di Indonesia. Ramuan tersebut diantaranya adalah: (1) perpaduan antara jenis musik, gaya dan olah tubuh yang sudah diprogramkan, (2) gaya dan tatanan vokal yang diudara oleh para penyiar yang appresiatif di dalam proses penyampaian berita serta programnya melalui beberapa editor siap tayang yang tidak boleh terabaikan, (3) teknik-teknik yang digunakan dalam proses iklan komersial serta iklan layanan masyarakat agar menjadi lebih hidup dan efektif. Yang dikemas dalam bentuk drama dan non drama, (4) Sound effect yang dapat menggugah emosi para pendengar dan pemirsanya disaat mengiringi penyiaran program, (5) Dukungan oleh alat-alat 
teknik perekaman produksi program penyiaran yang canggih, dan (6) bersifat terbuka dalam arti bahwa berita tersebut untuk khalayak atau publik yang tidak terbatas dan bersifat heterogen. Pemetaan publik sangat geografis tersebar di mana saja, siapa saja dan bersifat heterogen, kreatif dan kapan saja menurut Arifin, "Pada karakteristik program yang ditampilkan di televisi "voice over + Slide Bulletin, sinyal video dan audio berupa narasi, ringkasan atau summary" (Arifin, 2010).

Dari semua hasil-hasil produksi program siaran televisi yang menjadi kesamaan adalah produksi program informasi dan berita berupa layanan iklan, program pendidikan, politik, ekonomi dan berita keagamaan yang semuanya dikemas dengan illustrasi musik dengan tidak mengabaikan Standar Perilaku Program Siaran yang sudah di atur oleh pemerintah melalui KPI.

Program penyiaran televisi merupakan sebuah sistem dari sebuah stasiun televisi yang akan mempunyai rencana dan jadwal program acara tentunya format siaran akan disesuaikan dengan keadaan pasar, segmen dan khalayak. Serta penyesuaiannya akan disesuaikan dengan usia dan waktu penyiaran format tersebut. Dapat dikatakan secara umum program acara televisi di TVRI Bandung dapat dikategorikan sebagai berikut: (1) adanya sebuah sistem kerjasama dengan stasiun televisi lain. (2) adanya kerjasama dengan rumah produksi $(\mathrm{PH})$ dalam sistem jual lepas, sewa atau bagi hasil contohnya hiburan drama yaitu sinetron, film, gala sinema dan program Dunia Anak dan Sapa Mania Legend ini termasuk didalamnya. (3) adanya kerjasama dengan sponsor iklan, namun pada kedua program yang di tayangkan TVRI ini tidak terdapat iklan yang dikerjasamakan karena bersifat non komersial dan non profitable (4) ada pertukaran program acara pada pihak terkait, baik dalam bentuk hasil program atau secara pendidikan sumber daya manusia di dalam lingkungan manajemen TVRI.

Produksi program Televisi dapat dibagi menjadi empat besar, yaitu: (1) Produksi Non Drama (2) Produksi Drama (3) News (4) Produksi Iklan. Dari sekian banyak point diatas akan dibahas hanya pada point Produksi Non Drama saja dikarenakan pada Program Dunia
Anak dan Sapa Mania Legend termasuk dalam kategori tersebut. Berikut uraian pembahasan program produksi non drama yang adalah bersifat seperti News, pemberitaan, musik, kuis, vareaty show, talk show, dan magazine udara.

Program produksi non drama yaitu semua kegiatan didalam studio meliputiide dan gagasan yang akan disampaikan pada khalayak dalam bentuk secara langsung baik itu bersifat outdoor maupun indoor, tidak ada rekayasa dan alur cerita yang panjang. Bersifat faktual, akurat dan segar. Jenis program non drama salah satunya adalah musik, tak ada satu acara program pada televisi yang terlepas dari keterkaitan dengan musik dalam pengemasannya. Musik mempunyai kekuatan yang besar dan berpengaruh pada sebuah program, musik di dalam program dapat dikatakan sebagai "nyawa" namun yang dimaksudkan di dalam acara program musik disini dimana acara itu hampir keseluruhannya adalah musik, seperti konser, pergelaran, drama musikal, roadshow musik band, request, inbox ajang musik, peluncuran musik dan program yang disengaja untuk show musik.

Menurut Mc Quail, "Organisasi media massa memiliki tujuan yang beragam adalah penting untuk menempatkan media dalam konteks sosialnya" (Mc Quail, 2011). Berdasarkan hal itulah dapat dipahami bahwa beberapa penyebaran satu program televisi tanpa terstruktur akan dapat memengaruhi khalayak ramai dengan mudah. Pengaruh ini terdapat pada karakteristik personal dari sifat komunikasi massa jika ia tidak tersegmentasi dengan baik. Banyak studi terhadap program yang dilemparkan tanpa adanya riset terlebih dahulu terhadap khalayak dan ini menjadi pengaruh sosial yang berkesinambungan.

Ketakutan dan pengharapan yang berlebihan dalam literatur umum dan penelitian mengenai pengaruh meida terhadap anak-anak, terlepas dari isu kekerasan dan kejahatan. Banyak penelitian telah dilakukan terhadap penggunaan dan respons anak-anak terhadap media televisi dari awal hingga kini.

Ide-ide yang diungkapkan dan diuji mengenai efek yang tidak diinginkan adalah pengharapan dari media televisi adalah sebagai berikut: peningkatan dalam isolasi 
sosial; pengurangan waktu dan perhatian terhadap pekerjaan rumah; sifat pasif yang semakin meningkat; berkurangnya waktu untuk bermain dan berolahraga; menggurangi waktu untuk membaca; melemahkan otoritas keluarga; pengetahuan dan pengalaman seksual secara dini; kebiasaan makan tidak sehat dan obesitas; dukungan akan kecemasan terhadap citra diri yang berujung pada anoreksia; dan kecederungan depresif.

Efek menguntungkan dari program Dunia Anak TVRI adalah persyaratan sebagai basis untuk interaksi sosial; mempelajari mengenai dunia yang lebih luas; mempelajari sikap dan perilaku yang lebih luas; mempelajari sikap dan perilaku prososial; efek pendidikan; membantu membentuk identitas; dan membangun imajinasi. Hargrave dan Livingstone menyediakan pembahasan yang mendalam akan bukti bahaya dan penyerangan yang disediakan media dengan rujukan pada anak-anak. Ini merupakan kekhawatiran dampak program anak secara global namun pada Program Dunia anak TVRI tidak terdapat pengaruh hal tersebut (Mc Quail: 2011).

Hal-hal yang disampaikan tersebut di atas yang merupakan pengaruh atau dampak lain dari satu proram televisi yang tidak melalui implementasi yang sesuai dengan pedoman Standar Perilaku Penyiaran. Namun program Dunia anak yang ditayangkan TVRI telah sesuai dengan standar siaran hanya saja membutuhkan kejelasan dalam pemberian logo untuk segmentasi audiens.

Implementasi atau penerapan Pedoman Perilaku Penyiaran Dan Standar Program Siaran (P3SPS) pada program Sapa Mania Legend adalah di antaranya pada setiap bab yang bersinggungan Pada peraturan KPI tentang Pedoman Perilaku Penyiaran (P3) Bab XVII Pasal 21 ayat 2 seperti gambar 3.2. Pedoman Perilaku Penyiaran (P3) BAB XVII dijelaskan secara lengkap mengenai penggolongan program siaran berdasarkan usia khalayak atau penonton, berdasarkan ayat tersebut maka program Sapa Mania Legend diklasifikasikan sebagai program berklasifikasi SU (Semua Umur), hal ini juga telah disetujui oleh Bpk. Mukhtarudin S.ST. selaku produser Sapa Mania
Legend.

Namun demikian, pada peraturan KPI tentang Pedoman Perilaku Penyiaran (P3) Bab XVII Pasal 21 ayat 3 disebutkan bahwa lembaga penyiaran televisi wajib menayangkan klasifikasi program siaran secara jelas untuk memudahkan khalayak penonton mengidentifikasi program siaran, program Sapa Mania Legend tidak mencantumkan klasifikasi program siaran seperti yang telah ditetapkan dalam Pedoman Perilaku Penyiaran (P3).

Pada peraturan KPI tentang Pedoman Perilaku Penyiaran (P3) Bab XIX tentang Narasumber dan Sumber Informasi Bagian Kelima Wawancara Pasal 31 disebutkan bahwa lembaga penyiaran wajib memperoleh dan menyimpan identitas penelepon atau narasumber, dalam hal ini program Sapa Mania Legend sudah menjalankan prosedur yang sesuai mengenai memperoleh dan menyimpan identitas penelepon atau narasumber.

Pada peraturan KPI tentang Pedoman Perilaku Penyiaran (P3) Bab XXVI tentang Siaran Langsung disebutkan bahwa dalam memproduksi dan/atau menyiarkan program siaran langsung wajib berpedoman pada penggolongan program siaran, dalam hal ini, dari segi segmentasi audiens, durasi serta jam tayang program Sapa Mania Legend pada pelaksanaannya sudah sesuai dengan penggolongan program siaran.

Pada peraturan KPI tentang Standar Program Siaran (SPS) Bab XII tentang Pelarangan Dan Pembatasan Seksualitas pasal 20 dijelaskan setiap pelarangan muatan seks lirik lagu, suara, maupun gambar dalam video klip yang ditayangkan setiap program musik maupun program lainnya. Berdasarkan hasil penelitian, program Sapa Mania Legend tidak bertentangan dan dalam batasan yang diperbolehkan dalam hal muatan dan konten lagu dan video klip yang ditayangkan.

Pada peraturan KPI tentang Standar Program Siaran (SPS) Bab XVII tentang Penggolongan Program Siaran pasal 39, program siaran klasifikasi SU adalah program siaran yang berisikan muatan yang tidak secara khusus ditujukan untuk anak-anak dan remaja namun dianggap layak ditonton oleh anak-anak 
dan remaja. Berdasarkan bunyi pasal tersebut maka program Sapa Mania Legend sesuai sebagai program berklasifikasi SU (Semua Umur).

Berdasarkan jam tayang dan durasi penayangan program Sapa Mania Legend tidak bertentangan dengan Standar Program Siaran (SPS) Bab XVII tentang Penggolongan Program Siaran pasal 39, hal ini dikarenakan tidak ada penjelasan tentang jam tayang untuk program klasifikasi SU (Semua Umur), selain itu jam tayang program Sapa Mania Legend merupakan waktu orang tua berada dirumah sehingga penonton anak-anak dan remaja tetap ada dalam bimbingan orang tua saat menyaksikan televisi.

Pada peraturan KPI tentang Standar Program Siaran (SPS) Bab XIX tentang Hak Siar menjelaskan mengenai kewajiban mencantumkan hak siar, dan mencantumkan asal sumber potongan gambar yang diperoleh dari lembaga penyiaran lain atau sumber luar lainnya. Program Sapa Mania Legend sudah sesuai dengan Standar Program Siaran (SPS) Bab XIX tentang Hak Siar pasal 52 ayat 3 karena Sapa Mania Legend selalu mencantumkan dan menayangkan sumber gambar atau video klip luar yang digunakan dalam Program Sapa Mania Legend diantaranya situs berbagi video Youtube.

Situs berbagi video di Youtube ini merupakan inovasi terbarukan yang setiap saat dapat diakses oleh khalayak. Kebanyakan program memiliki tujuan yang campur aduk dan jarang dinyatakan terbuka namun pada program ini sangat terbuka dan bisa diakses oleh umum. Dimana kesesuaian standar program dan perilaku dalam implementasinya tidak ada penyimpangan yang berarti. Basis lain yang disarankan sesuai dengan pedoman adalah dapat dibedakan menurut jenis penerima manfaat. Tunstall dan Mc Quail menggambarkan tujuan dibuatkan program dalam media jika dilihat dari sudut pandang ekonomi dapat membedakan antara sasaran pendapatan dan sasaran non profit (Tunstall dan Mc Quail: 2011).

Hal ini mengacu pada tujuan-tujuan tanpa aspek finansial langsung, seperti prestise, memantapkan pengaruh atau kekuatan atas masyarakat atau meraih suatu tujuan normatif.
Jenis utama sasaran pendapatan dari Program ini ada dua: memperoleh keuntungan atau pemasukan dari penjualan langsung kepada konsumen pada saat air time berjalan ketika Youtube diakses dari penjual ruang untuk pengiklan. Jenis-jenis kebijakan publikasi yang berbeda menyesuaikan variasi sasaran (segmentasi).

Selain itu penayangan program ini bertujuan membentuk opini atau memberikan informasi yang jelas selain membawa ikon TVRI juga membawa ikon program ini sendiri. Beberapa implikasi pedoman dalam program ini adalah sebagai penyebaran pengaruh dan kemampuan ini memanfaatkan media televisi sebagai agen perubahan melalui program Sapa Mania Legend. Memang tujuan ini tidak bisa berdiri sendiri namun membawa entitas lembaga TVRI yang diberikan skalanya lebih besar.

Dilihat dari sudut pandang hubungan dengan kelompok-kelompok kepentingan dan tekanan pada Program Sapa Mania Legend ini, antara TVRI dan masyarakat seringkali memprakarsai serangkaian luas kelompok yang lebih dan berusaha menetapkan batasan terhadap apa yang dipublikasikan. Meski biasanya programmer berhati-hati dalam menangani tekanan dari masyarakat. Biasanya akses bergantung pada legitimasi lembaga TVRI itu sendiri.

Kecenderungan TVRI dalam program Sapa Mania Legend berusaha menyenangkan sebanyak mungkin khalayaknya, mencegah diri untuk menyakiti minoritas dan mendukung aktivitas sosial. Memberikan suguhan yang dapat memberikan stimulus yang baik terhadap khalayak dan mendapat respons yang baik pula agar menjaga keutuhan pemikiran masyarakat Indonesia terutama Jawa Barat berada dalam koridor yang sehat dan sama.

Implementasi atau penerapan Pedoman Perilaku Penyiaran Dan Standar Program Siaran (P3SPS) pada program Dunia Anak adalah di antaranya pada setiap bab yang bersinggungan dijelaskan dalam Pedoman Perilaku Penyiaran (P3). Pada peraturan KPI tentang Pedoman Perilaku Penyiaran (P3) Bab $\mathrm{X}$ tentang Perlindungan Kepada Anak menjelaskan pentingnya setiap lembaga penyiaran untuk 
menyiarkan program pada waktu yang tepat dan memperhatikan kepentingan anak. Program Dunia Anak merupakan program yang memperhatikan kepentingan anak sehingga sudah sesuai dengan Pedoman Perilaku Penyiaran (P3) Bab X tentang Perlindungan Kepada Anak.

Pada peraturan KPI tentang Pedoman Perilaku Penyiaran (P3) Bab XVII Pasal 21 ayat 2. Pedoman Perilaku Penyiaran (P3) BAB XVII dijelaskan secara lengkap mengenai penggolongan program siaran berdasarkan usia khalayak atau penonton, berdasarkan ayat tersebut maka program Dunia Anak diklasifikasikan sebagai program berklasifikasi P (Pra-Sekolah), dan A (Anak).

Namun demikian, pada peraturan KPI tentang Pedoman Perilaku Penyiaran (P3) Bab XVII Pasal 21 ayat 3 disebutkan bahwa lembaga penyiaran televisi wajib menayangkan klasifikasi program siaran secara jelas untuk memudahkan khalayak penonton mengidentifikasi program siaran, program Dunia Anak tidak mencantumkan klasifikasi program siaran seperti yang telah ditetapkan dalam Pedoman Perilaku Penyiaran (P3).

Pada peraturan KPI tentang Pedoman Perilaku Penyiaran (P3) Bab XIX tentang Anak-anak Dan Remaja Sebagai Narasumber dijelaskan secara lengkap mengenai ketentuanketentuan untuk menjadikan anak-anak sebagai narasumber. Dalam hal ini program Dunia Anak telah berpedoman pada Pedoman Perilaku Penyiaran (P3) Bab XIX tentang Anak-anak Dan Remaja Sebagai Narasumber karena dalam program Dunia Anak yang diwawancarai adalah anak-anak berprestasi dan pembahasan wawancara hanya mengenai prestasi yang sudah dicapai sang anak saja.

Pada peraturan KPI tentang Standar Program Siaran (SPS) Bab XVII tentang Penggolongan Program Siaran pasal 35 dan pasal 36 menjelaskan mengenai definisi program klasifikasi P (Pra-Sekolah), dan A (Anak), serta batasan dan larangan dalam hal muatan program-program berklasifikasi P (PraSekolah) dan A (Anak).

Pada Standar Program Siaran (SPS) Bab XVII tentang Penggolongan Program Siaran pasal 35 dan pasal 36 juga menyebutkan bahwa program berklasifikasi P (Pra-Sekolah) hanya boleh ditayangkan pada pukul 07.00 hingga pukul 09.00 dan antara pukul 15.00 hingga pukul 18.00. Sedangkan program berklasifikasi A (Anak) hanya boleh ditayangkan pada pukul 05.00 hingga pukul 18.00.

Program Dunia Anak pada pelaksanaannya telah sesuai dengan Standar Program Siaran (SPS) Bab XVII tentang Penggolongan Program Siaran karena tidak bermuatan konten yang dilarang dan jam tayang yang sesuai untuk program berklasifikasi P (Pra-Sekolah) dan A (Anak) yaitu pada pukul 15.30 WIB.

\section{SIMPULAN}

Berdasarkan hasil penelitian yang telah dilakukan pada program Sapa Mania Legend dan Dunia Anak di TVRI Jawa Barat serta analisa teori yang diperoleh dari tinjauan pustaka, maka dapat disimpulkan bahwa:

Sesuai dengan pernyataan Peraturan Komisi Penyiaran Indonesia No.01/P/ KPI/03/2012 bahwa Perilaku Penyiaran pada kedua program yang diteliti sudah sesuai dengan Standar Program Siaran yang memahami dan menggunakan pedoman batasan-batasan, pelarangan, kewajiban, dan pengaturan menyiarkan kedua program tersebut, sehingga tidak mendapatkan sanksi dari Komisi Penyiaran Indonesia (KPI).

Berikut efek reaksi kolektif dari program Dunia Anak dan Sapa Mania Legend TVRI dapat dihadapi dengan logika dari model stimulus respons walaupun elemen lain masih ada. Elemen baru umumnya berkaitan dengan cara dimana reaksi disiarkan kepada yang lain, seringkali pada kecepatan tinggi dan dengan penguatan tertentu atas efek keseluruhan. Oleh karena itu Sapa Mania Legend dilihat dari perspektif model komunikasi Stimulus Respons membawa pengaruh yang signifikan terhadap masyarakat.

Distribusi sosial dari pengetahuan yang didapatkan dari program Sapa Mania Legend ini adalah salah satu efek media yang besara dan diantisipasi secara luas-kapasitas mereka untuk memberikan informasi atau menginformasikan 
masyarakat skala besar dengan cara konsisten dengan kebutuhan dari ekonomi modern dan proses demokrasi partisipan. Telah lama diasumsikan bahwa program media dan penyiaran telah menambah banyak aliran informasi publik dan program acara yang membantu mengubah perbedaan pengetahuan yang disebabkan oleh ketidaksetaraan pendidikan dan posisi sosial.

Tujuan dan manfaat dari Pedoman Perilaku Penyiaran dan Standar Program Siaran adalah dalam rangka pengaturan perilaku lembaga penyiaran di Indonesia, yaitu agar pemanfaatan frekuensi televisi sebagai ranah publik yang merupakan sumber daya alam terbatas dapat senantiasa ditujukan untuk kemaslahatan masyarakat sebesar-besarnya, serta agar menjadi pedoman yang mendorong lembaga penyiaran untuk memperkukuh integrasi sosial, terbinanya watak dan jati diri bangsa yang beriman dan bertakwa, mencerdaskan kehidupan bangsa, memajukan kesejahteraan umum, dalam rangka membangun masyarakat yang mandiri, demokratis, adil, dan sejahtera.

Implementasi atau penerapan Pedoman Perilaku Penyiaran Dan Standar Program Siaran (P3SPS) pada program Sapa Mania Legend dan Dunia Anak adalah pada setiap bab yang bersinggungan diantaranya adalah:

Program Sapa Mania Legend: Pedoman Perilaku Penyiaran (P3) Bab XVII tentang Penggolongan Program Siaran, pada pelaksanaannya program Sapa Mania Legend sudah sesuai dengan Pedoman Perilaku Penyiaran dalam hal klasifikasi program. Namun demikian, program Sapa Mania Legend tidak mencantumkan klasifikasi program siaran seperti yang ditetapkan dalam Pedoman Perilaku Penyiaran Bab XVII Pasal 21 ayat 3.

Pedoman Perilaku Penyiaran (P3) Bab XIX tentang Narasumber dan Sumber Informasi Bagian Kelima Wawancara Pasal 31, pada pelaksanaannya program Sapa Mania Legend sudah sesuai dengan Pedoman Perilaku Penyiaran. Pedoman Perilaku Penyiaran (P3) Bab XXVI tentang Siaran Langsung, pada pelaksanaannya program Sapa Mania Legend sudah sesuai dengan Pedoman Perilaku Penyiaran.
Standar Program Siaran (SPS) Bab XII tentang Pelarangan Dan Pembatasan Seksualitas pasal 20, pada pelaksanaannya program Sapa Mania Legend sudah sesuai dengan Standar Program Siaran. Standar Program Siaran (SPS) Bab XVII tentang Penggolongan Program Siaran pasal 39, pada pelaksanaannya program Sapa Mania Legend sudah sesuai dengan Standar Program Siaran. Standar Program Siaran (SPS) Bab XIX tentang Hak Siar, pada pelaksanaannya program Sapa Mania Legend sudah sesuai dengan Standar Program Siaran.

Mengenai Program Dunia Anak, dalam Pedoman Perilaku Penyiaran (P3) Bab X tentang Perlindungan Kepada Anak, pada pelaksanaannya program Dunia Anak sudah sesuai dengan Pedoman Perilaku Penyiaran. Pedoman Perilaku Penyiaran (P3) Bab XVII tentang Penggolongan Program Siaran, pada pelaksanaannya program Dunia Anak sudah sesuai dengan Pedoman Perilaku Penyiaran dalam hal klasifikasi program. Namun demikian, program Dunia Anak tidak mencantumkan klasifikasi program siaran seperti yang telah ditetapkan dalam Pedoman Perilaku Penyiaran (P3) Bab XVII Pasal 21 ayat 3. Contohnya Logo (BO) yang bermakna Bimbingan Orangtua, (R) untuk Remaja, (D) Untuk Dewasa dsb.

Pedoman Perilaku Penyiaran (P3) Bab XIX tentang Anak-anak Dan Remaja Sebagai Narasumber, pada pelaksanaannya program Dunia Anak sudah sesuai dengan Pedoman Perilaku Penyiaran. Standar Program Siaran (SPS) Bab XVII tentang Penggolongan Program Siaran pasal 35 dan pasal 36, pada pelaksanaannya program Dunia Anak sudah sesuai dengan Standar Program Siaran.

Dampak yang ditimbulkan oleh tayangan televisi yang tidak sesuai dengan Pedoman Perilaku Penyiaran dan Standar Program Siaran serta dikonsumsi oleh khalayak yang tidak tepat adalah bila tayangan mengandung unsur negatif seperti kekerasan, eksploitasi seks, rasisme, dan lain sebagainya yang dapat memicu perilaku buruk pada khalayak.

Berdasarkan pembahasan diatas penulis berkesimpulan bahwa, Penerapan P3SPS maupun regulasi-regulasi penyiaran secara keseluruhan dapat diterapkan di TVRI Jawa 
Barat, namun secara teknik produksi untuk kedua program ini pada proses pembuatan program harus lebih jeli dalam penerapannya agar layak konsumsi masyarakat ketika ditayangkan dan tentunya akan memengaruhi pola pikir khalayak ramai. Selain itu TVRI Jawa Barat mampu berperan sebagai Media Literacy sosialisasi regulasi dan pedoman penyiaran bagi lembaga-lembaga penyiaran lainnya yang ada di Indonesia demi ketercapaian tujuantujuan yang ada pada P3SPS Komisi Penyiaran Indonesia.

\section{DAFTAR PUSTAKA}

Amalia, R. (2015). Efek tayangan on the spot terhadap pesan media massa bagi mahasiswa ilmu komunikasi universitas mulawarman. Seminar Efek Tayangan On The Spot Bagi Mahasiswa Ilmu Komunikasi. Kalimantan: Universitas Mulawarman.

Anggreani, W. (2015). Pengaruh reportase investigasi di Trans TV episode kosmetik palsu terhadap perilaku memilih kosmetik bagi ibu rumah tangga kelurahan bandara kota samarinda. eJournal Ilmu Komunikasi. Vol. 3 No. 2.

Arifin, E. (2010). Broadcasting to be broadcaster. Yogyakarta: Graha Ilmu.

Baksin, A. (2009). Jurnalistik televisi teori dan praktik. Bandung: Simbiosa Rekatama Media.

Cangara, H. (2006). Pengantar ilmu komunikasi. Jakarta: Raja Grafindo Persada.

Desti, S. (2005). Dampak tayangan film di televisi terhadap perilaku anak. Jurnal Komunikologi Vol. 2 No.1, Maret 2005. Jakarta: Universitas Esa Unggul.

Imran, H. A. (2012). Media massa, khalayak media, the audience theory, efek isi media dan fenomena diskrusif. Journal Studi Komunikasi
Dan Media Vol. 16 No. 2. BPPKI DKI Jakarta.

Kriyantono, R. (2007). Pemberdayaan konsumen televisi melalui keterampilan media literacy dan penegakan regulasi penyiaran. Jurnal Penelitian Komunikasi, Media Massa dan Teknologi Informasi. Vol. 10 No. 21.

Mc Quail, D, (2011). Teori komunikasi massa. Jakarta: Salemba Humanika.

Mega, S. dkk. (2013). Program Menu Sport di radio 107, 9 FM sebagai media penyebaran informasi olahraga di Jatinangor Kabupaten Sumedang. eJurnal Mahasiswa Unpad. Vol. 2, No. 2.

Kurniadi, O. (2013). Budaya jurnalistik di Metro TV. Jurnal Kajian Komunikasi. Vol. 1, No. 2. DOI: https://doi.org/10.24198/jkk.v1i2.6038.

Peraturan Komisi Penyiaran Indonesia Nomor 01/P/KPI/03/2012 tentang Pedoman Perilaku Penyiaran.

Peraturan Komisi Penyiaran Indonesia Nomor 02/P/ KPI/03/2012 tentang Standar Program Siaran.

Peraturan Komisi Penyiaran Indonesia Nomor 03 Tahun 2007 tentang Standar Program Siaran. Diakses dari https://www.kpi.go.id/download/ regulasi/PKPI_01_P KPI 07 2014.pdf.

Peraturan Pemerintah Republik Indonesia Nomor 50 Tahun 2005, Tentang Penyelenggaraan Penyiaran Lembaga Penyiaran Swasta. Diakses dari https://ppidkemkominfo.files.wordpress. com/2014/02/pp_no_50_th_2005.pdf.

PPRI Nomor 11 Tahun 2005, Tentang Penyelenggaraan Penyiaran Lembaga Penyiaran Publik.

Rakhmat, J. (2012). Metode penelitian komunikasi. Bandung: Remaja Rosdakarya.

Undang-Undang Republik Indonesia No. 32 Tahun 2002 tentang Penyiaran. Diakses dari https://www.komisiinformasi.go.id/regulasi/ download/id/137.

Wahyuni, I. (2014). Komunikasi massa. Yogyakarta: Graha Imu.

Zahroh, F. (2013). Dampak televisi terhadap perilaku anak sekolah. Jakarta: UIN Jakarta. 